Підкамінна, Людмила. «Власні назви Білорусі в українському поетичному дискурсі: прагматичний і стилістичний потенціал». Лінгвостилістичні студії, вип. 10, 2019, с. 144-153.

Pidkaminna, Liudmyla. "Linguostylistics of Neologisms in the Language of Modern Ukrainian Mass Media". Linguostylistic Studies, iss. 10, 2019, pp. 144-153.

УдК 811.161.2' $[37+42]$

https://doi.org/10.29038/2413-0923-2019-10-144-153

\title{
ЛІНГВОСТИЛІСТИКА НЕОЛОГІЗМІВ У МОВІ СУЧАСНИХ УКРАЇНСЬКИХ ЗМІ
}

\author{
Людмила Підкамінна \\ Національний педагогічний університет імені М. П. Драгоманова, \\ Київ, Україна
}

\begin{abstract}
У статті досліджено семантику, етимологію та стилістичні функції неологізмів у мові сучасних українських засобів масової інформації. Проаналізовано джерела виникнення нових слів, типологію запозичень. На основі фактичного матеріалу (друкованих та електронних 3МI) виділено й досліджено основні стилістичні функції лексичних інновацій у мас-медійному просторі. Вивчено використання різних типів неологізмів у мові сучасних українських 3MI.
\end{abstract}

Ключові слова: неологізм, засоби масової інформації, медіадискурс, лексичні інновації, стилістичні функції, неологізація, семантика.

Pidkaminna Liudmyla. Linguostylistics of Neologisms in the Language of Modern Ukrainian Mass Media. The article investigates semantics, etymology and stylistic functions of neologisms in the language of modern Ukrainian mass media. Lexical innovations arise as an individual phenomenon but are promulgated through the mass media and become commonly used. Therefore, processes of assimilation, use and replication of neologisms in mass media are an actual linguistic problem, the study of which will contribute to a deeper understanding of the peculiarities of the language development, as well as the general tendencies of integration of the Ukrainians into the world community.

The research analyzes the sources of new words and the typology of borrowing words. A significant amount of innovative vocabulary in modern Ukrainian mass media is a variety of borrowings, which in most cases do not have Ukrainian analogs and appear as a result of the lacunarity of the Ukrainian language or are borrowed from other languages as lexemes that have no equivalents in the taget language vocabulary. A number of common-breeding neologisms can be formed from foreign words in accordance with the typical of Ukrainian language word-formation model. In order to avoid oversaturation of the Ukrainian language with foreign lexics, the Ukrainians make attempts to create and use Ukrainian words instead of foreign neologisms.

The main stylistic functions of lexical innovations in the mass media, which are directly dependent on the author's interpretation and aimed at the elucidation of the communicative processes, have been identified and analyzed on the basis of the actual material from the printed and electronic mass media. The emphasis is laid on the use of different types of neologisms in the language of contemporary Ukrainian mass media. Further research is suggested to study the hybrid model of neologism word-formation.

(c) Підкамінна Л., Східноєвропейський національний університет імені Лесі Українки, 2019.

Це стаття відкритого доступу на умовах СC BY-NC 4.0 
Key words: neologism, media, media discourse, lexical innovations, stylistic functions, semantics.

Вступ. Розвиток нових інформаційних технологій, поступ людства та невпинні процеси глобалізації сприяють появі в мові нових реалій i, як наслідок - нових слів, що зумовлює поповнення тезаурусу неологізмами. Лексичні інновації виникають як індивідуальне явище, однак, поширюючись засобами масової інформації, стають загальновживаними. Тому процеси засвоєння, використання та тиражування неологізмів у $3 \mathrm{MI} \epsilon$ актуальною лінгвістичною проблемою, дослідження якої сприятиме глибшому розумінню особливостей розвитку мови, а також загальних тенденцій інтеграції українців у світову спільноту.

Неологізми як мовне явище завжди були об'єктом зацікавлень багатьох як вітчизняних, так і зарубіжних науковців. Українську неологію розвивали I. Андрусяк, Г. Вокальчук, В. Герман, А. Калєтнік, I. Самойлова, 0. Сербенська, Н. Стратулат, О. Стишов тощо. Останнім часом неологічні праці присвячені здебільшого дослідженню загальних лексикосемантичних та словотвірних особливостей лексичних інновацій. Зміни у лексичному складі української мови через призму засобів масової інформації вивчав О. Стишов. Лексичні інновації в мові хорватських засобів масової інформації 90-х років XX- початку XXI століття стали об'єктом вивчення О. Ткачук. Фразеологічні неологізми в сучасному українському мас-медійному дискурсі досліджувала Л. Пашинська. Проте з огляду на динамічність процесів виникнення та функціонування нових слів неолексику в сучасних українських засобах масової інформації вивчено недостатньо.

Мета статті - дослідження семантики, етимології та стилістичних функцій неологізмів у мові сучасних українських засобів масової інформації.

Матеріал і методи дослідження. Матеріалом для дослідження стали друковані та електронні засоби масової інформації (див. список використаних джерел). Метод компонентного аналізу використано для вивчення семантичної структури неологізмів. Квантативний метод дозволив підрахувати частотність вживання інноваційної лексики в одному виданні, метод контент-аналізу використано для дослідження змісту видання, порівняння способів актуалізації.

Результати дослідження. Неологізмом вважаємо «слово, а також його окреме значення, вислів, які з'явилися в мові на певному етапі їі розвитку i новизна яких усвідомлюється мовцями (загальномовні неологізми) або були вжиті тільки в якомусь акті мовлення, тексті чи мові певного автора (стилістичні, або індивідуально-авторські неологізми)» (Українська мова 377).

Нова лексема, як правило, виникає разом із новим поняттям, однак науковці виокремлюють загальномовні та індивідуально-авторські 
неологізми (Українська мова 377). Загальномовні неологізми позначають нове поняття, серед них розрізняють лексичні (запозичені нові слова або слова, утворені за типовими для мови моделями) й семантичні (наявні в мові слова, які вживають із новим значенням).

Причинами виникнення неологізмів зазвичай вважають:

1. Потребу назвати нове поняття, явище, яке раніше не існувало.

2. Необхідність замінити наявні назви більш точними.

3. Розвиток нових значень у словах, що вже існували в мові.

4. Бажання дати образну та незвичну назву явищу чи предмету (Сучасна 117).

Поява та функціонування інноваційної лексики зумовлені історично, адже неологізм існує лише до того часу, коли він стає узуальним і починає часто використовуватися значною кількістю мовців.

Нещодавно слова брокер, блог, веб-сторінка, таймер, тендер були неологізмами, однак зараз набули статусу загальномовних і в усьому світі сприймаються як загальновживані інтернаціоналізми. Тому в межах цього дослідження неологізмом вважатимемо слово, поява і використання якого датовані останніми п'ятьма-сімома роками. Переважна більшість таких слів ще не кодифікована, і відсутність дефініції у словниках - це ще одна характерна ознака неологізмів.

Виникнення нових слів часто зумовлене суспільно-політичними подіями в країні. Наприклад, в українській мові так з'явилися слова телемедицина, томос, євробляхи, євромайдан, небесна сотня, диванна сотня, зелені чоловічки, ЛНР, ДНР, ОРДЛО, ООС, сіра зона, мінські домовленості, країна-агресор тощо. Такі неологізми найчастіше з'являються в новинних повідомленнях, а потім поширюються усіма засобами масової інформації.

Умовно процес неологізації можна представити так: індивідуальне вживання неологізму $\rightarrow$ соціалізація нової лексеми (сприймання суспільством) $\rightarrow$ лексикалізація неологізму (закріплення в мовній системі).

Значна кількість інноваційної лексики в сучасних українських 3МI різноманітні запозичення, які в більшості випадків не мають українських відповідників, виникли внаслідок лакунарності української мови та запозичені з інших мов як безеквівалентна лексика: хештег (aнгл. hashtag, від hash - «символ гратки», «октоторп») - слово або фраза, яким передує символ «\#».

Серед основних джерел запозичень останніх років різноманітні інформаційні технології (IP-телефонія, селфі, гугл-диск, iPhone 6, iPad), Інтернет (емодзі, трафік, інтерфейс, контент, кеш, лінк, вебінар, софт, веб-сервіс, спам, хештег, бот), пов'язані з Інтернетом назви грошей, які використовують лише в кіберпросторі (криптовалюта, веб-мани, яндексгроші, біткоїн, інтернет-банкінг), реклама, бізнес (бутстрепінг, краудфандинг, віральність, лідогенерація, гроуз-хакінг), професійна сфера, в якій виникають назви нових професій (таргетолог, вчитель-тьютор, 
бренд-менеджер, верифікатор, редактор-копірайтер, трейдер, івентменеджер, супервайзер, девелопер, консультант-промоутер, хедхантер, дигер), дозвілля, шоу-бізнес, спорт (зорбінг, квілінг, тверк, гіроскутер, дауншифтинг, буккросинг, тизер, спінер, шопінг, челендж, перфоманс), індустрія краси (шугаринг, біоревіталізація, пілінг, боди-скраб, ліфтинг, sра-догляд, деспорт, antiage-програма, мезотерапія).

Від досить давно засвоєних іншомовних слів за типовими для української мови словотвірними моделями може утворюватися ціла низка спільнокореневих новотворів, формуючи словотвірне гніздо. Наприклад: Гугл - пошукова система, гуглонути - здійстинити одноразовий пошук, гуглань, гуглюк - людина, яка не вміє користуватися пошуковою системою, гугліж, гуглення - пошук, гугнило - те, за допомогою чого здійснюється пошук, гугломовець - мовець, який черпає інформацію 3 гугла, гугляр - той, для кого гуглити - забава, гуглізми - типові помилки гугл-перекладача, гуглема - одиниця смислу, яку гуглять, вгуглило - про значні результати пошуку та подібні. Крім того, в інтернет-спільнотах часто перефразовують відомі вислови, прислів'я та приказки, замінюючи певні слова новотворами із коренем гугл, такі фрази набувають іронічного смислу, наприклад: іди собі гуглом; недогугл у куплеті, перегугл у газеті; туди, де гугл-пошук не ганяв; без гугла день роком стає; був би гугл - все інше знайдеться; гугли до поту, а їж в охоту; на гугл надійся, та й сам розум май та інші. 3 назвою відомої пошукової системи придумали навіть скоромовку: всіх гуглів не вигуглити, не перевигуглити («Культ мови»).

Така тенденція зберігається й щодо неологізмів. Прикладом є слово 'фейк', яке з'явилося в українському медіапросторі п'ять років тому як назва для неправдивої інформації і навіть було використано Президентом України для означення виборів на непідконтрольних Україні територіях: фейкові вибори. Нині внаслідок подальшої афіксації з'явилося слово 'фейковість': «Є чіткі маркери, що вказують на реальність чи феейковість новонароджених, та й наявних структур» (Український тиждень (2019) 14). I навіть оказіоналізм 'фейкомет': «Остаточна відповідь „фейкометам" влади» (Фірсов). Подібний спосіб словотворення зумовив появу неологізму 'субсидіант', утвореного від узусного 'субсидія': «Таким субсидіантам гроші на руки не дадуть» (Експрес, 3). Багатою на подібні новотвори $\epsilon$ публічна блогосфера: «Три завдання „порохоботам", що тендерять харчування армї» (Чорновол).

Щоб уникнути перенасичення української мови іншомовною лексикою, спостерігаємо намагання українців створити й послуговуватися українськими відповідниками іншомовних неологізмів: барбершоп голярня, ріелтор - нерухомець, рекрутер - наймар, тьютор - наставник, меню - стравопис, ейчар - кадровик, фрілансер - вільнонайманещь, лайк вподобайка, дайвер - пірнальник, гейм-девелопер - розробник ігор, копірайтер - гаслотворець, краудфандинг - спільнокошт, репортер новинар, мерчендайзер - товарознавещь тощо. 
Однак такі спроби не завжди вдалі, бо зазвичай не зовсім точно відображають семантику запозичення. Наприклад, копірайтер (англ. copywriter - від сору - примірник і writer - письменник) - фахівець із написання рекламних та презентаційних текстів, а не лише гаслотворець. Лексему новинар запропоновано використовувати для позначення трьох номенів: репортер, журналіст та ньюзмейкер, а це не відображає суті названих понять.

Мовна практика засобів масової інформації найбільш чутлива до продукування лексичних інновацій. На думку О. Стишова, «мова українських мас-медіа віддзеркалює стан сучасної літературної мови, відбиваючи іiї багатофункціональність, ступінь інтелектуалізації, оновлення і стилістичне перегрупування словника» (Стишов, Динамічні процеси 12).

Аналіз фактичного матеріалу дозволив виокремити декілька основних стилістичних функцій неологізмів у сучасних українських 3МI:

1. Номінативно-експресивну - автор, називаючи нове поняття, транслює власне ставлення, моделюючи в такий спосіб рецепцію: «Опонентам нинішнього президента просто зручно розібрати розслідування на меми, щоб вдало використовувати їх у своїх кампаніях») (Український тиждень (2019) 6). Дуже популярними у медіа-контенті є різноманітні запозичення 3 інтернет-простору, де значення нового слова має ще й символічний характер, містить візуалізацію, справляючи відповідне враження на реципієнта: «ЄӘина відмінність у тому, що тільки кандидати мають звітувати про свої статки, і це новий привід для фейспалму» (Український тиждень (2019) 17). Фейспалм (від англ. face-обличчя, palm - долоня) ляск по чолу, популярний онлайн-вираз у вигляді фізичного жесту «обличчя, закрите однією рукою». В інтернет-обговореннях використовують для вираження безнадійності спілкування, а також у відповідь на помилкову інформацію. Особливою експресією характеризуються також лексеми, вжиті в лапках: «Вони $\epsilon$, але „іхтамнєт” (Експрес 4).

2. Емотивно-оцінну - адресант за допомогою неологізму передає свої емоції та ставлення до повідомлюваного, нав'язуючи в такий спосіб власне сприймання реципієнтові: «Як визначити перед вами психотерапевт чи психогвалтівник?» (Лисяна). Емотивно-оцінну функцію виконують різноманітні неологізми-словосполучення, які фактично є перифразами: токсичний альянс, неконтрольована територія, сіра зона, зона ООС.

3. Субститивну - заміна доречного в певному контексті й наявного в українській мові слова неологізмом іншомовного походження 3 метою увиразнення мовлення та впливу на читача: «Час вибрано вдало, і меседж цілком зрозумілий» (Український тиждень (2019) 6).

4. Характерологічну функцію виконують неологізми, які характеризують явища, осіб, сюди ж зараховуємо неологізми прикладкового типу (кандидат-шоумен, військовослужбовці-жінки, блогер-неоподатківець тощо): «Дуже добре, що сьогодні для військовослужбовців-контрактників по 
всій краӥні будують сучасні комфортабельні гуртожитки» (Украӥнський тиждень (2019) 10). Цікавими, але поодинокими є неологізми-фемінітиви, які дедалі частіше потрапляють на шпальти друкованих 3MI: «Саме через цей пігмент і з'являються веснянки, - пояснює лікарка-дерматологиня» (Експрес 24).

5. Інтегративну, коли неологізм $\epsilon$ питомою складовою контексту, інтегрує цей контекст у семантичну єдність, належить до безеквівалентної лексики і може бути замінений лише описово: «Cmapman з українським корінням залучив 8,4 мільйона доларів» («Стартап»). «Профілактика джетлегу, їжа в літаку та ще 5 лайфххків, які допоможуть легше подорожувати» («Профілактика»). Джетлег (англ. jetlag) - десинхронізації біологічних ритмів внаслідок швидкого перетину декількох часових поясів (наприклад, на літаку). Лайфхак (від англ. lifehacking) - корисна порада).

6. Соціально-комунікативну, в якій неологічна лексика $\epsilon$ способом комунікації 3 певною соціальною групою людей або ж наявна екстраполяція нових слів певної соціальної групи на широкий загал). Так, наприклад, деякі військові професіоналізми стали нормою в сучасних українських 3МI: зеленка, оборонка, передок, дашка (кулемет ДШК): «Чи здатна українська оборонка виробляти цілком нову техніку, а не тільки переробляти й модернізувати стару радянську?» (Український тиждень (2015) 18).

Стилістичні функції неологізмів у сучасних українських ЗМІ безпосередньо залежать від авторських, журналістських настанов. В одному контексті може вживатися декілька неологізмів, реалізуючи не одну стилістичну функцію, наприклад, інтегративну та характерологічну: «Жодні праймериз, такі популярні нині серед партій-новотворів, жодні вливання свіжої крові, напряму чи в обхід, цьому не здатні зарадити» (Український тиждень (2019) 14).

Сучасний медіадискурс під впливом неологізмів може зазнавати різноманітних семантичних модифікацій і трансформацій: «Найцікавіше, що на виборах відіграє роль перформанс не лише самих кандидатів, тому маємо справу <...> з медійною еквілібристикою на будь-який смак і в будьякій формі та з Facebook-війнами» (Український тиждень (2019) 17) Перформанс - вистава, дійство, поєднання різних видів мистецтва. У цьому контексті лексема перфоманс має значно ширшу семантику, ніж українські відповідники, в результаті чого контекст трансформується із стилістично нейтрального в емотивно-оцінний. Із цією ж метою автор вживає й неологізм Facebook-війни замість більш узвичаєного війни у Facebook.

3МI тиражують неологізми, у результаті чого нова лексика швидко поширюється, на її основі з'являються похідні утворення: «Порошенко пожалівся, що його тролять через телемедицину в селі» (Мазуренко); «Хайп для Мураєва. Просто прибуло б „маскі-шоу" на всі його підприємства» (Олещук); «Чалий: Пранкери намагаються 
дискредитувати Україну в США» («Пранкери»); «Через хейтерство $i$ образи ми можемо втратити країну» (Калашник).

Втім засвоєння і фунціонування неологізмів цілком залежить від апробації суспільною практикою: мовна практика соціуму дає відповідь на питання, чи існує потреба в такому позначенні понять і чи має слово синонімічні засоби у словниковому складі мови.

Цікаве з цього погляду функціонування лексеми колаборація в сучасних українських 3MI: у «Словнику української мови» та «Великому тлумачному словнику української мови» взагалі відсутня ця лексема, $\epsilon$ лише слова колабораціоніст та колабораціонізм: КОЛАБОРАЦІОНІ́ЗМзрадницьке співробітництво з фашистськими загарбниками в окупованих ними країнах під час Другої світової війни (Словник 4: 216). У словнику іншомовних слів зафіксовано такі значення слова «колабораціоніст» (від фp. collaboration - співробітництво): 1) людина, яка під час Другої світової війни співпрацювала з фашистськими загарбниками; 2) перен. зрадник, запроданець (Словник іншомовних 534). У сучасних 3МІ слово колаборація вживають здебільшого зі значенням «зрада національних інтересів»: «Це проросійська політична позиція. Фактично - колаборація» (Експрес 6). Однак розвинулося й інше значення - «творча співпраця для реалізації певного проекту в галузі економіки, науки, культури, мистецтва»: «Колаборація Google i Міносвіти: що вийшло?» (Черепова). Такі слововживання збагачують словник української мови, створюють передумови для нарощування стилістичних та семантичних відтінків.

Питомо українські лексичні інновації мають переважно оказіональний характер і зазвичай утворені суфіксальним, префіксальносуфіксальним способом (медведчуківці, майданівці), шляхом словоскладання в поєднанні з лексемою іншомовного походження (вірусубивця, комп'ютери-пророки, заробітчани-майданарбайтери). Більш уживаними $\epsilon$ різноманітні скорочення слів (нацвідбір, соцпакет, постпродакшн), а також неологізми, утворені в результаті контамінації (О. Селіванова називає такий спосіб телескопією (167)) (промоція (промоушн + акція), кучмономіка (Кучма + економіка), поро хоботи (Порошенко + бот).

Зрозуміти семантику індивідуально-авторського неологізму часто можна лише в контексті: «...усе, що нині докучає украӥнцям, - природний наслідок політичного кучмізму й неподоланої «кучмономіки» замість нормального народного господарства» (День 17). Ідентифікація нового слова в комунікативних процесах здійснюється носієм мови з урахуванням усталених мовних та соціокультурних еталонів, сформованих у процесі життя в конкретному суспільстві.

Значно менш частотні семантичні неологізми: хмара (інтернетресурс, який дозволяє закачувати й використовувати інформацію на віддалених серверах), глюкоза (програма із великою кількістю помилок), хом'як (домашня веб-сторінка). Іноді виникнення і значення семантичного 
неологізму тісно пов'язане із менталітетом та суспільними реаліями: «Інше питання - знахабнілі мажори, яким насправді байдуже, на чому заробляти» (Український тиждень (2019) 6). Такі лексичні інновації зрозумілі винятково в контексті, вони не мають відповідників у інших мовах, тому їх складно перекласти.

Висновки та перспективи досліджень. Отже, лексичний склад сучасної української літературної мови активно поповнюють засоби масової інформації. Мовна норма в публіцистичному дискурсі постійно випробовується суспільною практикою. Екстралінгвальні чинники зумовлюють продукування неологізмів із метою мовної економії, експресії чи новизни. Інноваційну лексику використовують для посилення прагматичної спрямованості мовлення, більшого впливу на адресата. Неологічна лексика у мові мас-медіа реалізує низку стилістичних функцій, спрямованих на увиразнення комунікативних процесів.

Динаміка оновлення лексичного складу сучасної української літературної мови створює передумови для подальших наукових пошуків у царині неології, зокрема перспективним $\epsilon$ порівняльне вивчення новотворів у різних мовах, а також дослідження гібридного словотворення неологізмів.

\section{Список використаних джерел}

Газета по-українськи, № 17(2181), 01 березня 2019 року.

Калашник, Павло. «Через хейтерство і образи ми можемо втратити країну». Громадське. URL: https://hromadske.ua/posts/cherez-hejterstvo-i-obrazi-mi-mozhemo-vtratitikrayinu-radnik-zelenskogo (31.03.2019).

День: щоденна всеукраїнська газета, № 159-160, 6-7 вересня 2013 року.

Експрес, № 9 (10016), 28 лютого - 07 березня 2019 року.

Лисяна, Галина. «Як визначити перед вами психотерапевт чи психогвалтівник?» Українська правда. URL: https://life.pravda.com.ua/columns/2019/03/31/ $236317 /$.

Мазуренко, Альона. «Порошенко пожалівся, що його тролять через телемедицину в селі». Українська правда. URL: https://www.pravda.com.ua/news/2018/06/14/ $7183329 /$.

Олещук, Петро. «Хайп для Мураєва». Украӥнська правда. URL: https://www.pravda. com.ua/columns/2018/06/10/7182917/.

«Пранкери намагаються дискредитувати Україну в CША». Українська правда. URL: https://www.pravda.com.ua/news/2018/11/19/7198715/.

«Профілактика джетлегу, їжа в літаку та ще 5 лафхаків, які допоможуть легше подорожувати». правда. https://life.pravda.com.ua/travel/2018/12/2/234382/.

Фірсов, Єгор. «Остаточна відповідь «фейкометам» влади». Украӥнська правда. URL: https://blogs.pravda.com.ua/authors/firsov/5c920dcae6dd3/.

Чорновол, Тетяна. «Три завдання «порохоботам», що тендерять харчування армії». Українська правда. URL: https://blogs.pravda.com.ua/authors/chornovol/ $5 \mathrm{c} 8 \mathrm{fc} 2 \mathrm{bc} 0 \mathrm{~d} 9 \mathrm{dd} /$.

«Стартап з українським корінням залучив 8,4 мільйона доларів». Українська правда. Економічна правда. URL: https://www.epravda.com.ua/news/2018/12/14/ $643604 /$. 
Український тиждень, № 9 (589), 1-6 березня 2019 року.

Український тиждень, № 3 (375), 23-29 січня 2015року.

Черепова, Тетяна. «Колаборація Google i Міносвіти: що вийшло?» Вежа. URL: https://vezha.net.ua/suspilstvo/kolaboraciya-google-i-minosviti-shho-vijshlo/ (20.11.2018) .

\section{Sources}

Hazeta po-ukrainsky, no 17(2181), 01 Mar. 2019.

Kalashnyk, Pavlo. "Cherez kheiterstvo i obrazy my mozhemo vtratyty krainu”. Hromadske. hromadske.ua/posts/cherez-hejterstvo-i-obrazi-mi-mozhemo-vtratiti-krayinuradnik-zelenskogo.

The Day, no 159-160, 6-7 Sep. 2013.

Expres, no 9 (10016), 28 Feb. -07 Mar. 2019.

Lysiana, Halyna. "Iak vyznachyty pered vamy psykhoterapevt chy psykhohvaltivnyk?" Ukrainska pravda. life.pravda.com.ua/columns/2019/03/31/236317/.

Mazurenko, Alona. "Poroshenko pozhalivsia, shcho yoho troliat cherez telemedytsynu v seli". Ukrainska pravda. www.pravda.com.ua/news/2018/06/14/7183329/.

Oleshchuk, Petro. "Khaip dlia Muraieva”. Ukrainska pravda. www.pravda.com.ua/columns/ 2018/06/10/7182917/.

"Prankery namahaiutsia dyskredytuvaty Ukrainu v USA". Ukrainska pravda. www.pravda.com.ua/news/2018/11/19/7198715/.

"Profilaktyka dzhetlehu, yizha v litaku ta shche 5 lafkhakiv, yaki dopomozhut lehshe podorozhuvaty". Ukrainska pravda. life.pravda.com.ua/travel/2018/12/2/234382/.

Firsov, Yehor. "Ostatochna vidpovid "feikometam" vlady". Ukrainska pravda. blogs.pravda.com.ua/authors/firsov/5c920dcae6dd3/.

Chornovol, Tetiana. "Try zavdannia "porokhobotam", shcho tenderiat kharchuvannia armii". Ukrainska pravda. blogs.pravda.com.ua/authors/chornovol/5c8fc2bc0d9dd/.

"Startap z ukrainskym korinniam zaluchyv 8,4 miliona dolariv". Ukrainska pravda. Ekonomichna pravda. www.epravda.com.ua/news/2018/12/14/643604/.

The Ukrainian Week, no 9 (589), 1-6 Mar. 2019.

The Ukrainian Week, no 3 (375), 23-29 Jan. 2015.

\section{Список використаної літератури}

Бойчук, Марія. Неологізми в заголовках інтернет-видань: структурно-семантичний та функціонально-стилістичний аспекти. Автореф. дис. ...канд. філол. наук: 10.02.01. Харків, 2013.

Бойчук, Наталія. «Функціонування неологізмів-телескопізмів в англомовних засобах масової інформації». Науковий вісник Міжнародного гуманітарного університету. Серія: Філологія, вип. №25, т. 1, 2016, с. 164-6.

Кузь, Галина. «Українська суспільно-політична неологія: лексика та фразеологія». Наукові записки Тернопільського національного педагогічного університету. Серія: Мовознавство, вип. II (24), 2014, с. 134-9.

«Культ мови». Редакторський портал. URL: http://redactor.in.ua/ru/language/ 6516.Kult_movi_Tsirk_na_drot\%D1\%96_abo_Yak_vi_pishete_slovo_onlayn

Пашинська, Людмила. Фразеологічні неологізми в сучасному українському масмедійному дискурсі. Автореф. дис. ...канд. філол. наук: 10.02.01. Київ, 2011.

Селіванова, Олена. Світ свідомості в мові. Черкаси, 2012.

Словник іншомовних слів, укл. Л. О. Пустовіт та ін. Київ: Довіра, 2000.

Словник української мови, за ред. І. К. Білодіда. В 11 т. Київ: Наукова думка, 1970-1980. 
Стишов, Олександр. Динамічні процеси в лексико-семантичній системі та в словотворі української мови кінці ХХ ст. (на матеріалі мови засобів масової інформації). Автореф. дис... д-ра філол. наук: 10.02.01. Київ, 2003.

Стишов, Олександр. «Семантичні неологізми в дискурсі українськомовних мас-медіа початку XXI століття». Філологічні студії. Науковий вісник Криворізького державного педагогічного університету, вип. 13, 2015, с. 364-74.

Стишов, Олександр. «Стилістично марковані лексичні неологізми в дискурсі 3МІ початку XXI століття». Лінгвістичні дослідження, вип. 47, 2018, с. 91-8.

Сучасна українська літературна мова. Лексикологія. Фонетика, за ред. А. К. Мойсієнка. Київ : Знання, 2010.

Ткачук, Ольга. Неологізми в мові хорватських засобів масової інформації 90-х років XX початку XXI cm. Автореф. дис. ...канд. філол. наук: 10.02.03. Київ, 2011.

Українська мова: енциклопедія, за ред. В. М. Русанівського, і О. О. Тараненка. Київ, 2000.

\section{References}

Boichuk, Mariia. Neolohizmy v zaholovkakh internet-vydan: strukturno-semantychnyi ta funktsionalno-stylistychnyi aspekty. PhD Thesis Abstract. Kharkiv, 2013.

Boichuk, Nataliia. "Functioning of Neologsms-telescopisms in English mass media". Scientific Herald of International Humanitarian University. Series "Philology", iss. 25, vol.1, 2016, pp. 164-6.

Kuz, Halyna. "Ukrainian Socio-Political Neology: Vocabulary and Phraseology". Naukovi zapysky Ternopilskoho natsionalnoho pedahohichnoho universytetu. Seriia: Movoznavstvo, iss. II (24), 2014, pp. 134-9.

"Kult movy". Redaktorskyi portal. http://redactor.in.ua/ru/language/6516.Kult_movi_ Tsirk_na_drot\%D1\%96_abo_Yak_vi_pishete_slovo_onlayn.

Pashynska, Liudmyla. Phraseological neologisms in modern Ukrainian discourse of massmedia. PhD Thesis Abstract. Kyiv, 2011.

Selivanova, Olena. Svit svidomosti v movi. Cherkasy, 2012.

Slovnyk inshomovnykh sliv, edited by L. O. Pustovit and all. Kyiv: Dovira, 2000.

Slovnyk ukrainskoi movy, edited by I. K. Bilodid. 11 vols. Kyiv: Naukova dumka, 1970-1980.

Styshov, Oleksandr. Dynamichni protsesy $v$ leksyko-semantychnii systemi ta $v$ slovotvori ukrainskoi movy kintsi XX st. (na materiali movy zasobiv masovoi informatsii). PhD Thesis Abstract. Kyiv, 2003.

Styshov, Oleksandr. "Semantic neologisms in the discourse of Ukrainian media at the beginning of the XXI century". Philological Studies. Scientific bulletin of Kryvyi Rih State Pedagogical University, iss. 13, 2015, pp. 364-74.

Styshov, Oleksandr. "Stylistically Marked Lexical Neologisms in the Media Discourse at the Beginning of the XXIst Century". Lingvistichni doslidzhennja, вип. 47, 2018, с. 91-8.

Suchasna ukrainska literaturna mova. Leksykolohiia. Fonetyka, edited by A. K. Moisiienko. Kyiv: Znannia, 2010.

Tkachuk, Olha. Neologisms in the language of the Croatian mass media of the 1990-s of the 20-th and the beginning of the 21-st centuries. PhD Thesis Abstract. Kyiv, 2011.

Ukrainska mova: entsyklopediia, edited by V. M. Rusanivskyi, and 0. 0. Taranenko. Kyiv, 2000. 